Article

\title{
Proteomics Revealed Distinct Responses to Salinity between the Halophytes Suaeda maritima (L.) Dumort and Salicornia brachiata (Roxb)
}

\author{
Jenifer Joseph Benjamin ${ }^{1}$, Begoña Miras-Moreno ${ }^{2, *}$, Fabrizio Araniti ${ }^{3}{ }^{\mathbb{C}}$, Hajar Salehi ${ }^{4} \mathbb{D}_{\text {, }}$ \\ Letizia Bernardo ${ }^{5}$, Ajay Parida ${ }^{1,6, *}$ and Luigi Lucini ${ }^{5}$ (D) \\ 1 Department of Plant molecular Biology, MS Swaminathan Research Foundation, III Cross Street, \\ Taramani Institutional Area, Taramani, Chennai 600113, India; jeniferjoseph@mssrf.res.in \\ 2 Council for Agricultural Research and Economics-Research Centre for Genomics and \\ Bioinformatics (CREA-GB), via San Protaso 302, 29017 Fiorenzuola d'Arda, PC, Italy \\ 3 Department of AGRARIA, University “Mediterranea” of Reggio Calabria, I-89124 Reggio Calabria, Italy; \\ fabrizio.araniti@unirc.it \\ 4 Laboratory of Plant Cell Biology, Department of Biology, Bu Ali Sina University, Hamedan 65178-38695, Iran; \\ h.salehi92@basu.ac.ir \\ 5 Department for Sustainable Food Process, Università Cattolica del Sacro Cuore, 29122 Piacenza, Italy; \\ 1_bernardo@libero.it (L.B.); luigi.lucini@unicatt.it (L.L.) \\ 6 Institute of Life Sciences, Department of Biotechnology, Government of India, Bhubaneswar 10, \\ Odisha 751023, India \\ * Correspondence: mariabegona.mirasmoreno@unicatt.it (B.M.-M.); director@ils.res.in (A.P.)
}

Received: 16 January 2020; Accepted: 6 February 2020; Published: 10 February 2020

check for updates

\begin{abstract}
Plant resistance to salinity stress is one of the main challenges of agriculture. The comprehension of the molecular and cellular mechanisms involved in plant tolerance to salinity can help to contrast crop losses due to high salt conditions in soil. In this study, Salicornia brachiata and Suaeda maritima, two plants with capacity to adapt to high salinity levels, were investigated at proteome level to highlight the key processes involved in their tolerance to $\mathrm{NaCl}$. With this purpose, plants were treated with $200 \mathrm{mM} \mathrm{NaCl}$ as optimal concentration and $500 \mathrm{mM} \mathrm{NaCl}$ as a moderate stressing concentration for 14 days. Indeed, $200 \mathrm{mM} \mathrm{NaCl}$ did not result in an evident stress condition for both species, although photosynthesis was affected (with a general up accumulation of photosynthesis-related proteins in S. brachiata under salinity). Our findings indicate a coordinated response to salinity in both the halophytes considered, under $\mathrm{NaCl}$ conditions. In addition to photosynthesis, heat shock proteins and peroxidase, expansins, signaling processes, and modulation of transcription/translation were affected by salinity. Interestingly, our results suggested distinct mechanisms of tolerance to salinity between the two species considered, with S. brachiata likely having a more efficient mechanism of response to $\mathrm{NaCl}$.
\end{abstract}

Keywords: salt stress; plant proteomics; Chenopodiaceae; photosynthesis; signaling; osmotic stress

\section{Introduction}

Soil salinity is one of the primary causes of crop losses worldwide. Every year, about 1.5 million hectares of agriculture lands are affected by high salinity and rendered unsuitable for crop production [1,2]. Salinity affects about $20 \%$ of irrigated land primarily due to improper agricultural practices [3]. Many studies on current saltwater and freshwater interactions in coastal aquifers have demonstrated the increasing global problem of saltwater intrusion [4,5]. Soil salinization severely affects agricultural productivity, because most crops cannot tolerate sodium ion $\left(\mathrm{Na}^{+}\right)$concentrations 
greater than 150-200 $\mathrm{mM} \mathrm{NaCl}[6,7]$. Most of the plants can adapt to low or moderate saline conditions, but their growth is severely reduced above $200 \mathrm{mM} \mathrm{NaCl}$. Salinity imposes an initial osmotic effect and a subsequent ionic effect, reducing the ability of plants to uptake water and micronutrients [8]. Understanding the molecular and cellular mechanisms of salt tolerance are critical to help improve plant growth and productivity under saline conditions.

Halophytes are efficient in adaptation and have a well-orchestrated mechanism in place to deal with salinity stress $[9,10]$. They are able to complete their life cycle in saline conditions. The ability to regulate the amount of salt translocated to the shoot through the transpiration stream might be a determining factor in salt tolerance [8]. Halophytes can attain this $\mathrm{Na}^{+}$and $\mathrm{Cl}^{-}$(chloride) exclusion under high saline conditions [11]. In mangroves, $\mathrm{Na}^{+}$exclusion from the xylem is carried out through anatomical adaptations that reduce or prevent apoplastic movement of solution from outside the roots to the xylem; this ensures that cellular membranes and transporters can determine the ions which pass into the xylem [12]. In order to decrease the net uptake of salt ions to the shoots, halophytes display reduced stomatal opening which leads to the generation of ROS. The capability of halophytes to handle with ROS was studied in Eutrema parvulum, a close relative of Arabidopsis thaliana [13].

Numerous studies are being performed in diverse halophytes to understand and identify the genes responsible for salt tolerance [14,15]. Despite various salt stress-responsive genes have been reported, a complete understanding of salt tolerance mechanism still remains elusive. Halophytes capability to adapt to high salinity levels is often ascribed to regulation at both transcriptional and proteomic levels [16]. Proteins act as a major stimulator of plant stress response. Proteins not only act as enzymes but also as a key component in the transcription and translation processes, thereby plant stress response genes are regulated both at RNA and protein level [17]. However, stress response genes expressed at mRNA and protein level cannot be correlated due to the post-transcriptional and post-translational modifications in the former [18]. Several salt stress responsive proteins are expressed at different cellular functions such as signal transduction, regulation of carbohydrate, nitrogen and energy metabolism, RNA and protein synthesis, ROS regulation and redox homeostasis. Hence, quantitative proteomics is a prominent tool to be applied to study the salinity stress tolerance in plants. Such studies have been carried out in halophytes such as Thellungiella halophila [19], Suaeda aegyptiaca [20], Bruguiera gymnorhiza [21], as well as in Sesuvium portulacastrum [22].

Salicornia brachiata Roxb and Suaeda maritima (L.) Dumort, belong to the Chenopodiaceae family $[23,24]$. They are herbaceous, annual halophytes widespread in the pichavaram mangroves, Tamil nadu, India. Both species have a succulent shoot and are known to be salt-accumulators growing well at a salt concentration of $200 \mathrm{mM} \mathrm{NaCl}$ [25-27]. Previous metabolomic studies, carried on S. brachiata and S. maritima treated with $\mathrm{NaCl} 200 \mathrm{mM}$ and $500 \mathrm{mM}$, highlighted that these two halophyte species adopted different metabolic mechanisms to achieve acclimation to salinity. Anyway, in both species was observed an accumulation of osmoprotecctants (e.g., glycine betaine and polyols) suggesting that osmotic stress and oxidative imbalance adjustments were the key processes involved in $\mathrm{NaCl}$ tolerance [28]. Although $\mathrm{Na}^{+}$accumulation, effects on plant growth, as well as metabolic changes induced by $\mathrm{NaCl}$ have been largely characterized [25,28-30], few studies have been focused on salinity-induced protein variations in S.maritima and S. brachiata. Furthermore, previous research indicate that these two species are expected to exploit different mechanisms to adapt to salinity.

Therefore, the aim of this study was to comparatively investigate, through a proteomic approach, the impact of $\mathrm{NaCl}$ on protein profile and content of S. brachiata and S. maritima. This information could provide an additional insight on plant salt stress tolerance, eventually supporting the scientific efforts to develop salt tolerant crop species.

\section{Results}

To investigate the effect of salinity, the changes at proteome level in S. brachiata and S. maritima treated with $\mathrm{NaCl} 200$ and $500 \mathrm{mM}$ were analyzed through a shotgun MS approach. 
In a preliminary step, the unsupervised hierarchical cluster analysis were performed to have an overview of the protein profiling. The results pointed out that S. brachiata and S. maritima presented different profile based on proteins, as expected, since two main cluster separated both species (Figure 1). Moreover, $200 \mathrm{mM} \mathrm{NaCl}$ and $500 \mathrm{mM} \mathrm{NaCl}$ had different effect on plant proteins cauterizing in two different cluster within the species.

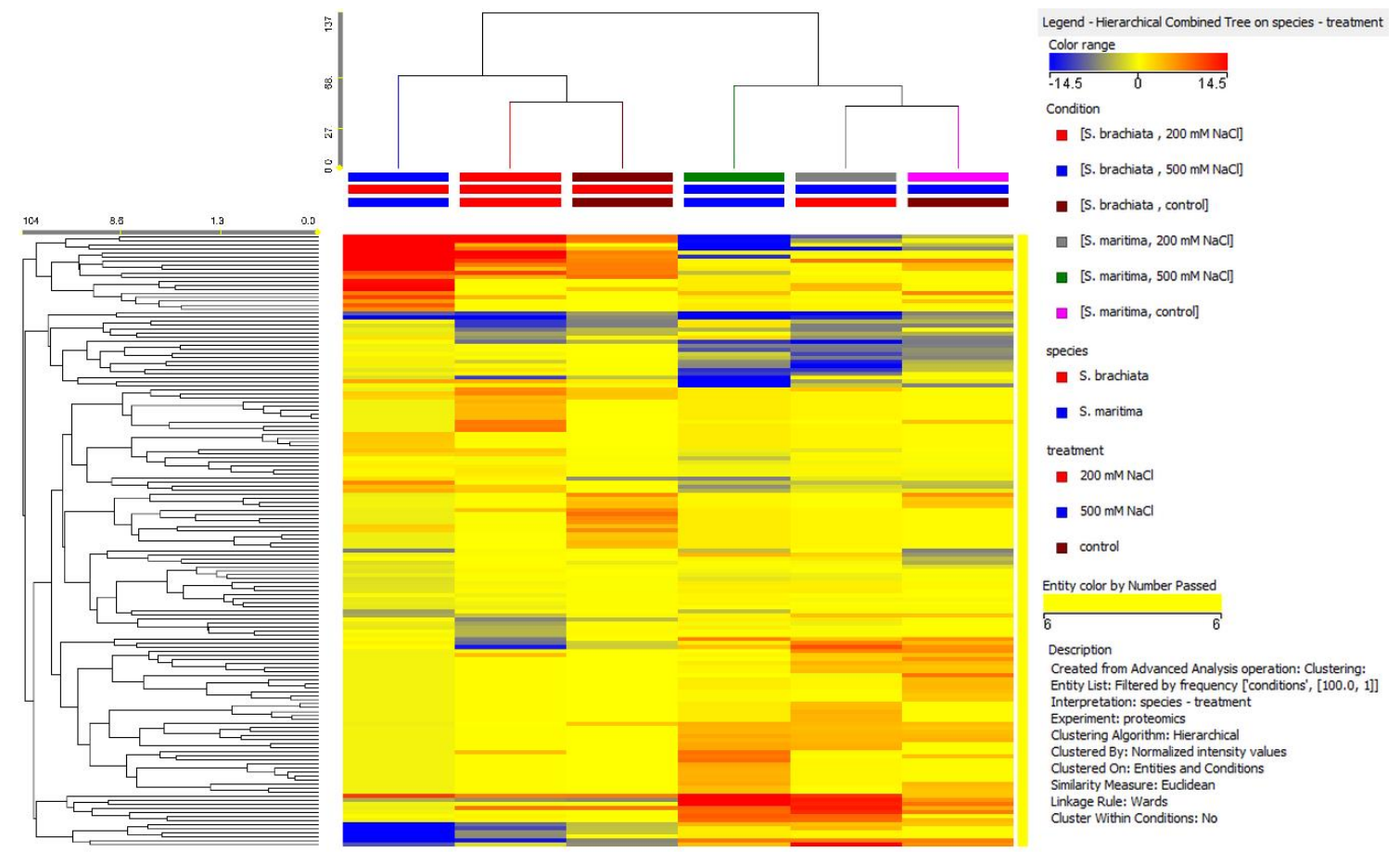

Figure 1. Unsupervised hierarchical cluster analysis of Salicornia brachiata and Suaeda maritima treated with $200 \mathrm{mM} \mathrm{NaCl}$ and $500 \mathrm{mM} \mathrm{NaCl}$. Clustering was carried out on both conditions (treatments, vertical dendrogram) and compounds (proteins, horizontal dendrogram).

Overall, 150 proteins have been identified after validation of the results (false discovery rate $=1 \%$ ). Significant features have been then identified through multivariate statistics, using the software Mass Profiler Professional (Agilent Technologies, Santa Clara, CA, USA). The whole datasets of proteins identified in S. brachiate and S. maritima are provide as supplementary material in Table S1 and Table S2, respectively. A multivariate partial least square discriminant analysis (PLS-DA) was subsequently carried out in S. brachiate (Figure 2) and S. maritima (Figure 3). This supervised analysis showed a clear separation between treatments being the accuracy of prediction $100 \%$. Those proteins characterized by the highest score in the PLS-DA model underwent a fold-change analysis using a cut-off value of 5.

Functional annotation revealed that the proteins regulated by salt stress could be grouped into few categories. Regarding S. brachiata, photosynthesis, response to osmotic/oxidative stress, transcription, protein metabolism, cell wall and cytoskeleton, as well as signaling resultingly affected by salinity (Table 1). However, photosynthesis, energy and amino acids metabolism, cell structure, cell cycle, transcription, and protein metabolism were modulated in S. maritima (Table 2). 
Table 1. Discriminant proteins in Salicornia brachiata shoots under either $200 \mathrm{mM}$ and $500 \mathrm{mM} \mathrm{NaCl}$ salinity, together with fold-change (FC) values and regulation.

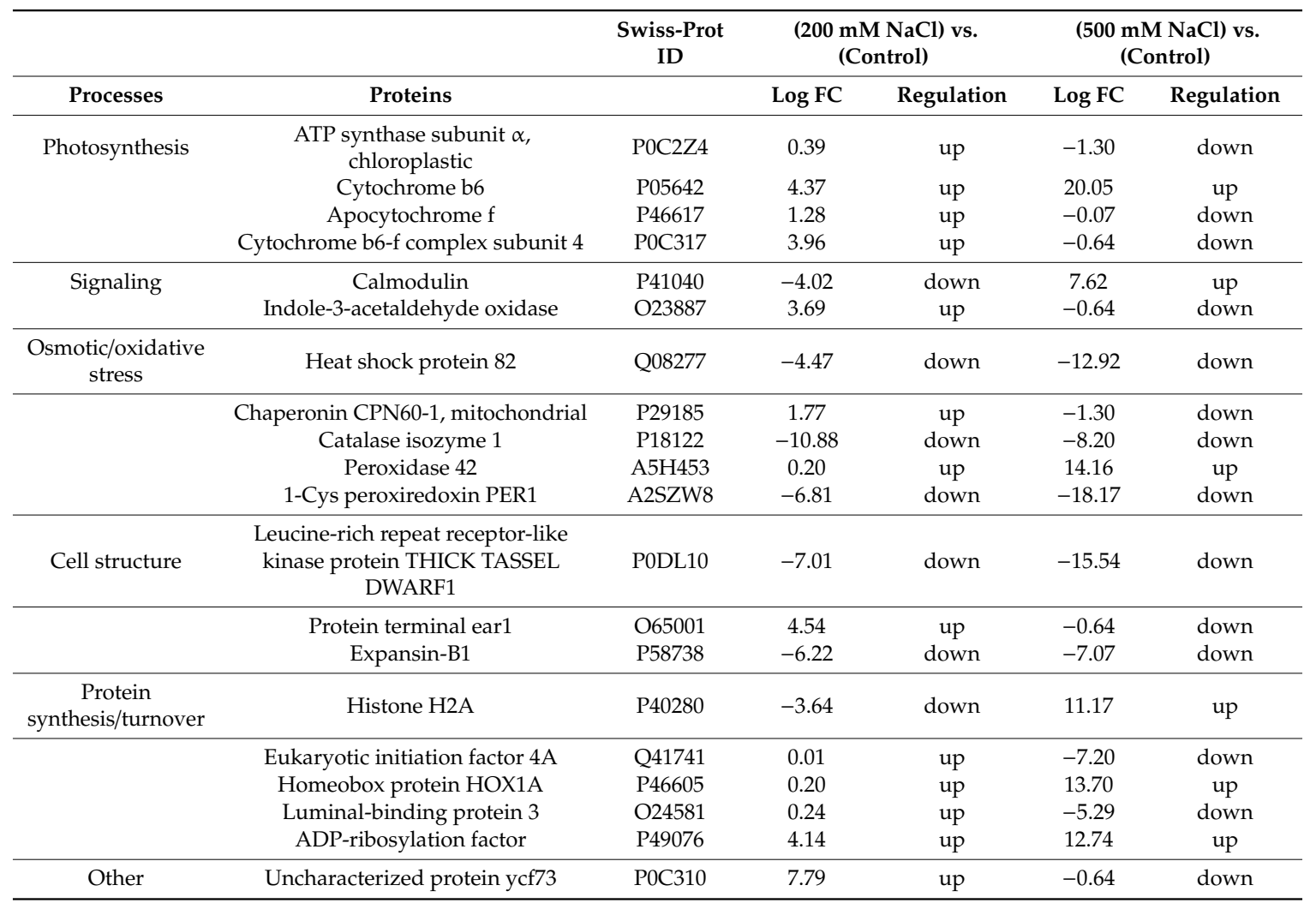

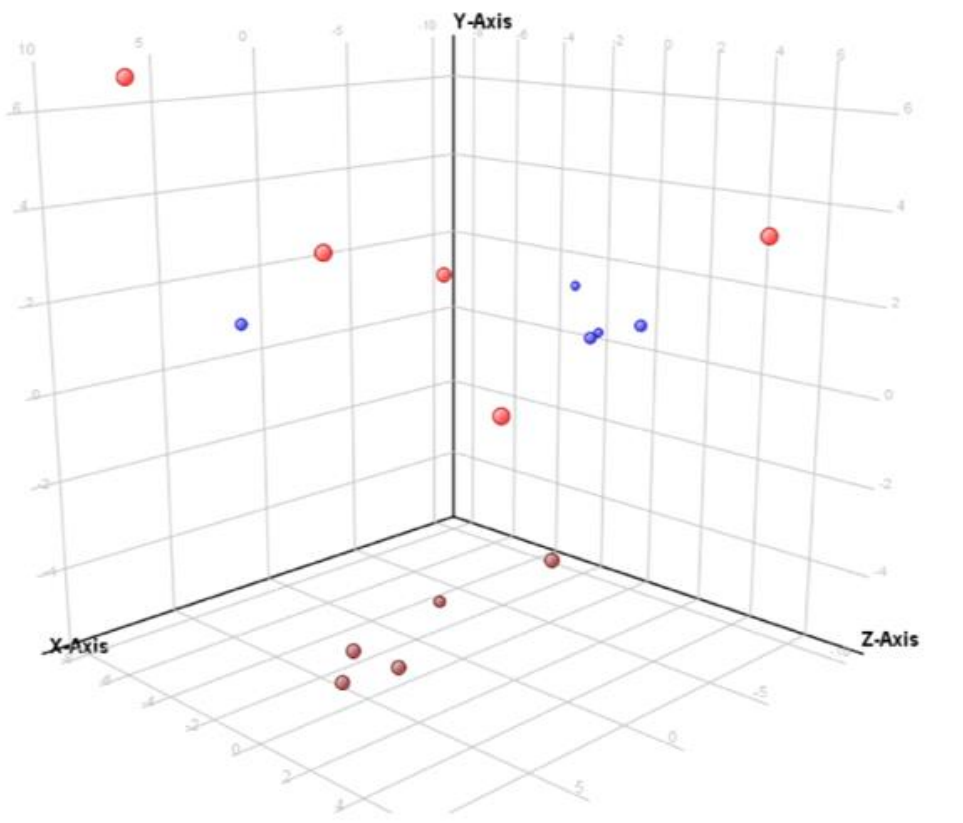

Legend - $\mathrm{t}$-Scores
Color by treatment (Non-averaged)
$[200 \mathrm{mM} \mathrm{NaCl}]$
$[500 \mathrm{mM} \mathrm{NaCl}]$
[ $[$ control]

Figure 2. Partial least squares discriminant analysis (PLS-DA) on Salicornia brachiata according to their protein response to $200 \mathrm{mM} \mathrm{NaCl}$ and $500 \mathrm{mM} \mathrm{NaCl}$. Individual replications are given in the class prediction model score plot. 
Table 2. Discriminant proteins in Suaeda maritima shoots under either $200 \mathrm{mM}$ and $500 \mathrm{mM} \mathrm{NaCl}$ salinity, together with fold-change (FC) values and regulation.

\begin{tabular}{|c|c|c|c|c|c|c|}
\hline \multirow[b]{2}{*}{ Processes } & \multirow[b]{2}{*}{ Proteins } & \multirow[t]{2}{*}{$\begin{array}{l}\text { Swiss-Prot } \\
\text { ID }\end{array}$} & \multicolumn{2}{|c|}{$\begin{array}{c}\text { (200 } \mathrm{mM} \mathrm{NaCl} \text { ) vs. } \\
\text { (Control) }\end{array}$} & \multicolumn{2}{|c|}{$\begin{array}{c}(500 \mathrm{mM} \mathrm{NaCl}) \text { vs. } \\
\text { (Control) }\end{array}$} \\
\hline & & & $\log$ FC & Regulation & $\log$ FC & Regulation \\
\hline \multirow[t]{8}{*}{$\begin{array}{l}\text { Photosynthesis } \\
\text { and Energy } \\
\text { metabolism }\end{array}$} & $\begin{array}{l}\text { Ribulose bisphosphate carboxylase } \\
\text { large chain }\end{array}$ & P00874 & -0.35 & down & -1.06 & down \\
\hline & $\begin{array}{l}\text { Glyceraldehyde-3-phosphate } \\
\text { dehydrogenase A, chloroplastic }\end{array}$ & P09315 & -0.60 & down & -0.69 & down \\
\hline & $\begin{array}{l}\text { Glyceraldehyde-3-phosphate } \\
\text { dehydrogenase 2, cytosolic }\end{array}$ & Q09054 & -0.01 & down & 0.68 & up \\
\hline & Cytochrome b6 & P05642 & 3.33 & up & -11.89 & down \\
\hline & Apocytochrome f & P46617 & 4.05 & up & -11.04 & down \\
\hline & Photosystem I iron-sulfur center & Р0С359 & 3.14 & up & -2.90 & down \\
\hline & $\begin{array}{l}\text { ATP synthase subunit } \alpha, \\
\text { chloroplastic }\end{array}$ & $\mathrm{P} 0 \mathrm{C} 2 \mathrm{Y} 5$ & -0.15 & down & -12.21 & down \\
\hline & Pyruvate decarboxylase 1 & P28516 & 0.31 & up & 4.09 & up \\
\hline $\begin{array}{l}\text { Amino acids } \\
\text { metabolism }\end{array}$ & Acetolactate synthase 1 , chloroplastic & Q41768 & 8.01 & up & -2.72 & down \\
\hline Cell Structure & Actin-1 & P02582 & 0.25 & up & -14.96 & down \\
\hline Cell cycle & Retinoblastoma-related protein 1 & Q9LKX9 & 0.27 & up & 0.38 & up \\
\hline \multirow[t]{3}{*}{ Transcription } & $\begin{array}{l}\text { DNA-directed RNA polymerase } \\
\text { subunit beta }\end{array}$ & P0C501 & 0.31 & up & 7.83 & up \\
\hline & Histone H4 & P62787 & 0.29 & up & -0.70 & down \\
\hline & Protein HIRA & Q32SG6 & -0.35 & down & 3.54 & up \\
\hline \multirow[t]{2}{*}{$\begin{array}{l}\text { Protein } \\
\text { synthesis/turnover }\end{array}$} & $60 S$ acidic ribosomal protein $\mathrm{P0}$ & $\mathrm{O} 24573$ & 8.42 & up & 9.96 & up \\
\hline & Ubiquitin-40S ribosomal protein S27a & P27923 & -0.78 & down & -1.32 & down \\
\hline Other & $\begin{array}{l}\text { CRS2-associated factor } 1, \\
\text { chloroplastic }\end{array}$ & Q84N49 & 0.31 & up & 7.99 & up \\
\hline
\end{tabular}

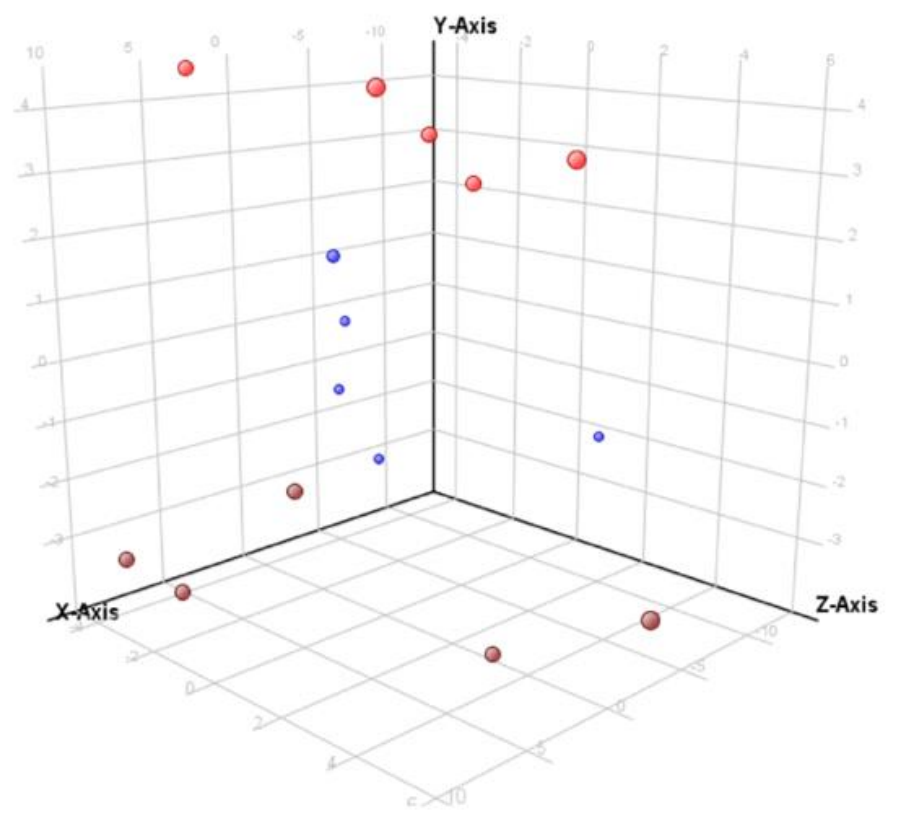

Legend $-t$-Scores
Color by treatment (Non-averaged)
[ $[200 \mathrm{mM} \mathrm{NaCl}]$
- $[500 \mathrm{mM} \mathrm{NaCl}]$
- [control]

Figure 3. Partial least squares discriminant analysis (PLS-DA) on Suaeda maritima according to their protein response to $200 \mathrm{mM} \mathrm{NaCl}$ and $500 \mathrm{mM} \mathrm{NaCl}$. Individual replications are given in the class prediction model score plot. 


\subsection{Photosynthesis and Energy Metabolism}

In S. brachiata, cytochrome b6 that up-accumulated at both $\mathrm{NaCl}$ concentrations, the most of photosynthesis-related proteins (ATP synthase subunit alpha, apocytochrome $\mathrm{f}$, cytochrome b6-f complex subunit 4) pointed out an up-accumulation at the lowest concentrations and a down-accumulation at the highest (Table 1).

In S. maritima, the level of cytochrome b6, apocytochrome f, photosystem I iron-sulfur center were up and down-accumulation at 200 and $500 \mathrm{mM} \mathrm{NaCl}$, respectively. On the contrary, ribulose bisphosphate carboxylase large chains and ATP synthase subunits were down-accumulated at both salt conditions. The protein chloroplastic glyceraldehyde-3-phosphate dehydrogenase A, involved in energy metabolism, was down-accumulated at both $\mathrm{NaCl}$ concentrations, while cytosolic glyceraldehyde-3-phosphate dehydrogenase 2 showed a contrasting behavior being down-accumulated at the lowest $\mathrm{NaCl}$ concentration and up-accumulated at the highest. Finally, the level of pyruvate decarboxylase 1 was up-accumulated at both $\mathrm{NaCl}$ concentrations (Table 2).

\subsection{Amino Acids Metabolism}

Acetolactate synthase 1 was the protein, involved the amino acid metabolism, which was significantly affected in S. maritima pointing out an up- and down-accumulation at 200 and $500 \mathrm{mM}$ $\mathrm{NaCl}$ treatments, respectively (Table 2).

\subsection{Stress and Defense-Related Proteins}

In S. brachiata, the proteins related to oxidative/osmotic stress such as heat shock protein 82 , catalase isozyme 1 and 1-Cys peroxiredoxin PER1 were down-accumulated. On the contrary, the level of peroxidase 42 was up-accumulated under both salt conditions, whereas chaperonin CPN60-1 was up-accumulated at $200 \mathrm{mM} \mathrm{NaCl}$ but down-accumulated at $500 \mathrm{mM} \mathrm{NaCl}$ (Table 1).

\subsection{Protein Folding and Degradation-Related Proteins}

In S. brachiata, the proteins related to transcriptional regulation, homeobox protein HOX1A and ADP-ribosylation factor were up-accumulated at both salt treatments. Nonetheless, the proteins related to protein synthesis, turnover were also altered by salinity. The level of eukaryotic initiation factor $4 \mathrm{~A}$, luminal-binding protein 3 were up-accumulated at $200 \mathrm{mM} \mathrm{NaCl}$ but down-accumulated at $500 \mathrm{mM}$ salinity, while the expression of histone $\mathrm{H} 2 \mathrm{~A}$ was down- and up-accumulated at $200 \mathrm{mM}$ and $500 \mathrm{mM}$ $\mathrm{NaCl}$, respectively (Table 1).

In S. maritima, the proteins related to transcription like DNA-directed RNA polymerase subunit beta were up-accumulated at both concentrations. The level of histone H4 were up- (200 mM) and down-accumulated $(500 \mathrm{mM})$ while protein HIRA was down $(200 \mathrm{mM})$ and up-accumulated $(500 \mathrm{mM})$ by $\mathrm{NaCl}$ treatments. Moreover, ribosomal proteins altered their abundance during salinity stress. In particular, at both $\mathrm{NaCl}$ concentrations the $60 \mathrm{~S}$ acidic ribosomal protein $\mathrm{P} 0$ was up-accumulated, whereas the Ubiquitin-40S ribosomal protein S27a was down-accumulated (Table 2).

\subsection{Cell Organization-Related Proteins}

In S. brachiata the protein expansin-B1 was down-accumulated at both salt treatments, while the leucine-rich repeat receptor-like kinase protein, a protein promoting vegetative meristem, was down-accumulated. However, the protein terminal ear1 (regulating leaf initiation rate and shoot development) [31] was up-accumulated at $200 \mathrm{mM} \mathrm{NaCl}$ pointing out an opposite trend at the highest concentrations (Table 1).

In S. maritima, the level of Actin-1 was up and down-accumulated at 200 and $500 \mathrm{mM} \mathrm{NaCl}$, respectively. Furthermore, an up-regulation of the gene encoding 'Retinoblastoma' (required for cell-cycle progression, endoreplication, transcriptional regulation, chromatin remodelling, and cell growth) was observed (Table 2). 


\subsection{Signaling-Related Proteins}

Significant differences in signaling-related proteins were only observed in S. brachiata. Calmodulin, $\mathrm{a} \mathrm{Ca}^{2+}$-dependent signalling molecule involved in the signaling network that mediates $\mathrm{Na}^{+}$homeostasis and salt tolerance [32], was down and up-accumulated at $200 \mathrm{mM}$ and $500 \mathrm{mM} \mathrm{NaCl}$, respectively. On the contrary, indole-3-acetaldehyde oxidase, a protein involved in auxin biosynthesis, was up-accumulated at lowest concentration assayed and down-accumulated at the highest (Table 1).

\section{Discussion}

The adaptive response of plants to various abiotic stress is mainly interceded by profound alteration in gene expression, which leads to changes in composition of plant transcriptome, proteome and metabolome. A number of studies have previously reported that the changes in gene expression at RNA level does not always correlate with the protein level [33]. The analysis of alteration in plant proteome is significant because proteins are key regulators of cellular responses and are also mainly involved in stress tolerance. Therefore, a proteomic investigation provides a powerful tool to reveal the potential associations between the protein expression and plant stress acclimation. Thus, proteomics is helpful to achieve a better understanding of the plant system under saline environment. On this basis, we conducted a study focusing on the changes in protein profile of S. brachiata and S. maritima as triggered by $\mathrm{NaCl}(0,200,500 \mathrm{mM})$.

Among the metabolic processes altered by salinity, photosynthesis was one of the most affected. Salinity alters plant water uptake and induces a quick response in stomatal conductance through biosynthesis of abscisic acid and SOS signaling in leaves. This affects photosynthetic electron transport chain and the activities of enzymes involved in carbon fixation [34]. At the lowest concentration assayed (200 $\mathrm{mM})$, the two species responded in a completely different manner. In particular, a generalized protein up accumulation was observed in S. brachiata. On the contrary, in S. maritima several proteins involved in photosynthesis (including RuBisCO and the chloroplastic glyceraldehyde-3-phosphate dehydrogenase A) were down accumulated by the treatment. Previous studies reported that $200 \mathrm{mM}$ induced an increment of both fresh and dry weight in S. brachiata, suggesting that this salt concentration is optimal to improve its growth and development [25]. On the contrary, in S. maritima, concentrations $\geq 200 \mathrm{mM}$ improved plant growth but the increase in fresh weight was mainly due to water accumulation rather than dry biomass production, indicating that this species activates physiological and biochemical mechanisms to tolerate salinity by mitigating and/or avoiding $\mathrm{NaCl}$ negative effects $[35,36]$.

Among the proteins belonging to the photosynthesis and energy metabolism, cytochrome b6, Apocytochrome $\mathrm{f}$ and the chloroplastic ATP synthase subunit $\alpha$ have been identified in both species (S. brachiata and S. maritima). Previous studies demonstrated that cytochrome b6, and the chloroplastic ATP synthase subunit $\alpha$ play a pivotal role in response to several stresses [37]. During salinity stress, transpiration is reduced by stomatal closure and by a salinity-induced thickening of the mesophyll which reduces $\mathrm{CO}_{2}$ diffusion, as a consequence the availability of $\mathrm{CO}_{2}$ to the Calvin-Benson cycle might be limited [38]. Moreover, the increase of photorespiration cannot fully compensate for reduced $\mathrm{CO}_{2}$ availability as alternative sink for NADPH and ATP. In addition, either photorespiration or Calvin-Benson cycle might be repressed in response to both severe salinity and drought stress by a biochemical limitation of primary metabolism, even though RuBisCO levels are weakly affected by salinity [39-41]. Consequently, in response to long-term salinity stress, the electron transport of the photosynthetic machinery needs to be repressed, to avoid a large disproportion between the metabolic demand and the electron transport capacity. For example, during drought stress, Helianthus annuus strongly decreases the ATP synthase content and activity, reducing the ATP availability for RuBisCO regeneration and slowing down, as a consequence, the activity of the Calvin-Benson cycle [41]. Several studies focused on changes in electron transport and leaf assimilation capacity revealed a close correlation between cytochrome b6f complex and the electron transport capacity. In fact, it has been demonstrated that the inhibition of the cytochrome b6f complex induced a proportional decrease of both linear electron flux and leaf assimilation [42,43]. Moreover, during stress conditions and 
senescence, ATP synthase content was repressed in parallel in response to a reduced metabolic demand for ATP and NADPH [44,45].

On the other hand, only when the reduction in ATP synthase content is higher than $50 \%$ a linear reduction of the ATP synthase activity and assimilation could be observed [46].

In S. brachiata, cytochrome b6f complex and the chloroplastic ATP synthase subunit $\alpha$ were up accumulated at $200 \mathrm{mM} \mathrm{NaCl}$ whereas ATP synthase was weakly down accumulated at $500 \mathrm{mM} \mathrm{NaCl}$. On the contrary, in S. maritima, both proteins where strongly down accumulated at the highest salt concentration (with chloroplastic ATP synthase subunit $\alpha$ having the same trend at $200 \mathrm{mM} \mathrm{NaCl}$ ), suggesting a reduction of the photosynthetic activity. In fact, the decrease of ATP synthase levels indicates the disturbance in energy metabolism caused by salinity, as previously observed in other species such as S. salsa and Thellungiella [47]. Nonetheless, these findings are in agreement with the lower tolerance of S. maritima to $\mathrm{NaCl}$, as compared to S. brachiata.

In addition to chloroplastic responses, the enzymes involved in glycolysis were also affected by salt treatments, but only in S. maritima. This effect was much less evident in S. brachiata, where a fold change lower than five was observed. Glycolysis is a pivotal pathway for energy production in plant cells. The alteration in the glycolytic enzymes NAD $(\mathrm{P}) \mathrm{H}$-dependent glyceraldehyde-3-phosphate dehydrogenase (GAPDH) and pyruvate decarboxylase (which, together with alcohol dehydrogenase, catalyse the decarboxylation of pyruvate to acetaldehyde and the reduction of acetaldehyde to ethanol) confirms the increase in catabolic energy production during salinity [48]. GAPDH is necessary to balance of cellular ATP levels and carbohydrate metabolism, thus affecting the energy status in plant and supporting its growth [49]. A down-regulation of the ATP synthase we observed at both concentration in S. maritima, and the down-regulation of both cytosolic and chloroplastic GAPDH further supports the lower tolerance to salinity of this species.

Plant stress adaptation is considered by an effectual adjustment of cellular metabolism to changing environmental conditions. During acclimation, the accumulation of numerous protective proteins and detoxification associated ROS scavenging enzymes occur to minimize the harmful effects of increased amounts of toxic by-products of altered cellular metabolism [17,50]. It is well known that one of the main targets of $\mathrm{NaCl}$ is the impairment of the mitochondrial function. Our results showed that in S. brachiata heat shock proteins (HSPs), which protect Complex I electron transport and might have a role in adaptation to $\mathrm{NaCl}$ [51], are affected by $\mathrm{NaCl}$. In addition, Hamilton and Heckathorn [52] demonstrated that Complex electron transports could also be protected by antioxidants and metabolites as proline and betaine. In our previous experiments we demonstrated that 200 and $500 \mathrm{mM} \mathrm{NaCl}$ treatment strongly induced the production of several antioxidant compounds (flavonoids, phenolics etc) in S. brachiata as well as proline (only in roots), glycine betaine and polyols concentration, suggesting that the plant was able to cope with stress protecting cell from reactive oxygen species production [28]. In addition, our hypothesis is strongly supported by the significant up accumulation of the peroxidase, which is crucial for the detoxification of any excess $\mathrm{H}_{2} \mathrm{O}_{2}$ produced by SOD during salinity stress and which is known to increase under salinity [52].

Furthermore, salinity stress extremely affects the stability/composition of the cytoskeleton [53]. It has been proven that there is a strict positive correlation between the response of salinity-induced reduction of expansins, components of the cell wall, and plant growth [54]. In fact, they play an important role in increasing wall flexibility and in promoting leaf growth under drought and salinity stress [55]. In our experiments, expansin-B1 abundance was reduced, at both $\mathrm{NaCl}$ concentrations, only in S. maritima, whereas in S. brachiata it was not significantly affected.

As expected, cell signaling was affected by salinity treatments, through the modulation of secondary messengers (via both leucine-rich repeats receptor-like protein kinases and ADP-ribosylation factor ARF1). Plant leucine-rich repeats receptor-like protein kinases (LRR-RLKs), which play important roles in the signal perception, amplification and transduction to abiotic stress, were found to be down-regulated in S. brachiata. Changes in abundance of several cytoskeletal and cytoskeleton-associated proteins like actin and retinoblastoma-related protein, both necessary during 
cell cycle and cytokinesis, have been observed in salt treated plant cells [47,56-59]. In our experiment, ADP-ribosylation factor ARF1 was accumulated under both treatments in S. brachiata. It has been largely reported that ARF1 might play an important role in plant response to abiotic stresses. Joshi et al. [59] reported that transformed Arabidopsis and rice plants overexpressing the ARF1 gene, cloned from the halophyte Spartina alterniflora, where characterized by a strongly increased resistance to salinity and drought stress Similarly, also Karan and Subudhi [60] demonstrated the direct involvement of an ARF gene (namely SaARF) in abiotic stress adaptation in S. alterniflora. In particular, they observed that the SaARF gene was transcriptionally regulated in both leaves and roots under enhanced salinity and drought, and mediated tolerance to multiple abiotic stresses. Both experiments demonstrated that that transformed Arabidopsis and rice seedlings overexpressing SaARF where characterized by an increased tolerance to drought by maintaining chlorophyll synthesis, a high relative water content, membrane stability, and an increased biosynthesis of osmoprotectants.

In addition, [61] observed that in transformed tabacum plants the gene ARF1 conferred heat stress resistance and stimulated seed germination during adverse conditions.

The modulation of both transcription and translation was also outlined in our experiments at various levels. In fact, this latter level of regulation included alterations in histones, translational initiation factors and a homeobox protein levels. In eukaryotes, histone proteins are subjected to various post-translational modifications including acetylation, methylation, phosphorylation, ubiquitination, sumoylation, and ADP ribosylation [62]. In our experiments, histone H2A was down accumulated at the lower salinity dosage and up accumulated at the higher dosage in S. brachiata. However, histone $\mathrm{H} 4$ was up and down accumulated at the lower and the higher $\mathrm{NaCl}$ dosage respectively, in S. maritima. Previous studies have revealed that the occupancy of each histone variant of a core histone, in particular H2A and H3, plays important roles not only gene expression, but also in the repair of DNA breaks and the assembly of chromosome centromeres in eukaryotes [63-65]. Moreover, Sokol et al. [66] reported that both tobacco and Arabidopsis cells exposed to salinity stress showed the typical nucleosomal response that included histones modification. Eukaryotic translational initiation factor $4 \mathrm{~A}$ (eIF4A) belongs to the family of helicases, important proteins involved in several cellular and metabolic processes including abiotic stress tolerance in plants [67]. Our results showed that eIF4A was up accumulated in S. brachiata at the lower dosage and down accumulated at higher dosage. The involvement of eIF4A genes in abiotic stress tolerance has been reported for several plant species like tobacco [68], rice [69], pea [70,71], and groundnut [72]. A transgenic approach highlighted the role of eIF4A genes in abiotic stress tolerance highlighted a reduced accumulation of sodium as primary mechanism [68,73]. Homeobox transcription factors are involved in various aspects of plant development, including the biosynthesis and signaling pathways of different hormones [74]. Our studies found that Homeobox protein HOX1A was up accumulated under salinity in S. brachiata. In literature, is reported that transgenic lines overexpressing HOX1A were characterized by an enhancement of gibberellin (GA) response [74]. These results are in agreement with our previous findings were an up accumulation of several gibberellins has been observed in S. brachiata treated with $\mathrm{NaCl}[28]$.

Furthermore, in our experiment, Luminal-binding protein 3 was up accumulated at the lower $\mathrm{NaCl}$ dosage and down accumulated at the higher $\mathrm{NaCl}$ dosage, in S. brachiata. This protein belongs to the HSP 70 superfamily and is involved in endoplasmic reticulum (ER) quality control mechanisms by recognizing unfolded or abnormally folded proteins thus avoiding their accumulation in the ER lumen [75] and the subsequent impairment of its secretory activity [76].

\section{Materials and Methods}

\subsection{Plant Material and Salt Treatment}

Seeds of S. brachiata and S. maritima were collected from Pichavaram, Tamil Nadu, India. The seeds of S. maritima and S. brachiata were germinated in vermiculite filled pots. The rooted plants were 
shifted to hydroponics containing modified Hoagland's medium [36] and maintained at $25 \pm 2{ }^{\circ} \mathrm{C}$ with a 16/8 $\mathrm{h}$ light/dark photoperiod. The plants were acclimatized for seven days in modified Hoagland's medium and treated with 0 (control treatment), 200 and $500 \mathrm{mM} \mathrm{NaCl}$ for 14 days. The nutrient solution was replaced with freshly prepared solution at seven-day intervals.

The choice of the concentrations was based on previous experiments which demonstrated that the concentration $200 \mathrm{mM}$ stimulated biomass production in both species whereas concentrations higher than $400 \mathrm{mM}$ induced a reduction in plant growth and development [25,77]. On these bases, we decided to use $\mathrm{NaCl}$ at $0 \mathrm{mM}$ as control treatment, $200 \mathrm{mM}$ as optimal concentration and $500 \mathrm{mM}$ as a moderate stress concentration. Harvesting (10 plants per treatment) was performed during daytime and the tissues were snap-frozen and powdered in liquid nitrogen to quench the endogenous metabolism and then stored at $-80^{\circ} \mathrm{C}$ for subsequent analyses.

\subsection{Protein Extraction}

Proteins were extracted as previously described by Lucini and Bernardo [48]. In Brief, $100 \mathrm{mg}$ of powdered shoot tissues were suspended in $0.8 \mathrm{~mL}$ protein extraction buffer. An equal volume of Tris-buffered phenol ( $\mathrm{pH} 8.0$ ) was also added, then shaken well and centrifuged at 15,000 $\mathrm{g}$ for $5 \mathrm{~min}$ at $4{ }^{\circ} \mathrm{C}$. The upper phase was transferred to the new tube and 5 volumes of precipitation solution (ice cold $0.1 \mathrm{M}$ ammonium acetate in methanol) were added. The mixed solution was incubated overnight at $-20^{\circ} \mathrm{C}$ and centrifuged at $10,000 \times g$ for $15 \mathrm{~min}$ at $4{ }^{\circ} \mathrm{C}$. The obtained pellet was then washed three times with $80 \%$ acetone $(v / v)$ and air dried. Finally, the dried pellet was resuspended in a buffer containing $3 \mathrm{M}$ urea and $2 \mathrm{M}$ thiourea. Protein concentration was estimated, using the Bio-Rad protein assay kit according to the manufacturer's instructions, and using bovine $\gamma$-globulin as standard. Protein samples were stored at $-20^{\circ} \mathrm{C}$ for further use. Finally, $50 \mu \mathrm{g}$ of proteins were taken and reduced with dithiothreitol (DTT), alkylated with iodoacetamide and followed by an overnight digestion with trypsin (Promega, Madison, WI, USA) at $37^{\circ} \mathrm{C}$.

\subsection{Proteomic Analysis by Tandem-MS}

Tryptic peptides were analysed by means of a shotgun LC-MS/MS through a hybrid quadrupole-time-of-flight (Q-TOF) mass spectrometer. In particular, an Agilent 6550 IFunnel Q-TOF mass spectrometer, equipped with a nano-LC Chip Cube source (Agilent Technologies, Santa Clara, CA, USA) was used. The chip was composed by both a $40 \mathrm{~nL}$ enrichment column (Zorbax300SB-C18, $5 \mu \mathrm{m}$ pore size) and a150 $\mathrm{mm}$ separation column (Zorbax300SB-C18, $5 \mu \mathrm{m}$ pore size) coupled to an Agilent Technologies 1200 series nano/capillary LC system. All the instrument modules were controlled by the Mass Hunter Workstation Acquisition (Agilent Technologies, Santa Clara, USA) (version B.04).

Peptides were then loaded into the trapping column with a flow rate of $2.6 \mu \mathrm{L} \mathrm{min}^{-1}$ in using a solution composed by $2 \%$ acetonitrile $(v / v)$ and acidified with $0.1 \%(v / v)$ formic acid. After the enrichment step, the chip was switched to separation mode and peptides were back flush eluted into the analytical column, during a $150 \mathrm{~min}$ acetonitrile gradient (from 3 to $70 \% v / v$ ) in $0.1 \%(v / v)$ formic acid at a flow rate of $0.3 \mu \mathrm{L} \mathrm{min}{ }^{-1}$. The mass spectrometer worked in positive ion mode and MS scans were acquired over a range from 300 to $1700 \mathrm{~m} / \mathrm{z}$ at 4 spectra $\mathrm{s}^{-1}$. Precursor ions were selected for auto-MS/MS at an absolute threshold of 1000 and a relative threshold of $0.01 \%$ and considering a maximum of 20 precursors per cycle and an active exclusion set at two spectra (with release after 0.2 min). Afterwards, Spectrum Mill MS Proteomics Work bench (Agilent Technologies, Santa Clara, CA, USA) (RevB.04;) was used for the analysis of MS/MS spectra for peptides identification. Auto MS/MS spectra were extracted from raw data accepting a minimum sequence length of three amino acids and merging scans with the same precursor within a mass window of $\pm 0.4 \mathrm{~m} / \mathrm{z}$ in a time frame of \pm 30 s. Search parameters were: (a) Scored Peak Intensity (SPI) $\geq 50 \%$, (b) precursor mass tolerance of $\pm 10 \mathrm{ppm}$, and (c) productions mass tolerance of $\pm 20 \mathrm{ppm}$. Carbamidomethylation of cysteine was set as fixed modification while trypsin was selected as digestion enzyme, accepting two missed cleavages per peptide. The search was conducted using the section "plants" in UniProt [78]; the database was 
concatenated with the reverse one. Auto thresholds were used for peptide identification in Spectrum Mill to achieve a target $1 \%$ false discovery rate. A label-free quantitation, using the protein summed peptide abundance was carried out following identification.

\subsection{Statistical Analysis}

The experiments were carried out in a completely randomized design with triplicates for reproducibility. The raw data on proteins signal intensities were imported into the Mass Profiler Professional B.04 (Agilent Technologies, Santa Clara, CA, USA) for multivariate statistical analysis. Protein intensities were $\log 2$ normalized and baselined versus the control. Afterwards, the dataset was elaborated through partial least squares discriminant analysis (PLS-DA) supervised multivariate statistics $(\mathrm{N}$-fold validation $=5$ ). The proteins having the highest discrimination score in first and second latent vector were finally exported from loading plots and then subjected to fold-change analysis (fold-change cut-off $=5$ ).

\section{Conclusions}

Plant proteome analysis is postulated as a powerful tool to shed light onto the physiological response to environmental stresses, since proteins are key regulators of cellular responses. In our study, two distinct protein profiles were observed between the halophytes considered under $\mathrm{NaCl}$ salinity. These findings suggest diverse mechanism of resistance to $\mathrm{NaCl}$ in S. brachiata and S. maritima. Overall, $500 \mathrm{mM} \mathrm{NaCl}$ implied a stress situation for both plant species. Proteomics revealed that a key process for plant development such as photosynthesis was affected by salinity in both cases. However, S. brachiata showed a positive response to $200 \mathrm{mM} \mathrm{NaCl}$, while S. maritima presented a down-accumulation of photosynthesis-related proteins after $\mathrm{NaCl}$ addition.

Although a coordinate proteomic response to salinity could be observed in both halophytes, the modulation of other stress-related processes was again different between S. brachiata and S. maritima. This coordinate response involved secondary processes crucial for plant survival, including plant signaling, heat shock proteins related to folding and mitochondrial electron transport chain, peroxidase, modulation of cytoskeleton (expansins), and regulation of both transcription and translation.

In addition to the distinct mechanisms adopted, the specific differences observed between the two halophytes corroborate the hypothesis that S. brachiata exhibits a higher tolerance to salinity, compared to $S$. maritima. These points deserve future attention, when halophytes are to be adopted as model plants to gain insight into plants tolerance to salinity.

Supplementary Materials: The following are available online at http://www.mdpi.com/2223-7747/9/2/227/s1, Table S1. Whole dataset of proteins identified in Salicornia brachiata. Table S2. Whole dataset of proteins identified in Suaeda maritima.

Author Contributions: J.J.B. and L.L. conceived and designed the work; L.L. supervised the proteomics analysis and cured the data. J.J.B., L.B. and H.S. contributed to formal analysis; F.A., B.M.-M., A.P., and J.J.B. assembled and interpreted the data. J.J.B., F.A., and B.M.-M. edited the draft article. L.L. critically revised the article; J.J.B., F.A., B.M.-M., and L.L. approved the final article. All authors have read and agreed to the published version of the manuscript.

Funding: This research received no external funding.

Acknowledgments: The authors thank the "Romeo ed Enrica Invernizzi foundation" for its partial support to the metabolomics core facility at Università Cattolica del Sacro Cuore. J.J.B. was recipient of short term fellowship from European Molecular Biology Organization, within the framework of her Ph.D. work.

Conflicts of Interest: The authors declare no conflicts of interest.

\section{References}

1. Carillo, P.; Annunziata, M.G.; Pontecorvo, G.; Fuggi, A.; Woodrow, P. Salinity stress and salt tolerance. In: Abiotic stress in plants-mechanisms and adaptations. IntechOpen 2011, 1, 21-38. 
2. Munns, R. Genes and salt tolerance: Bringing them together. New Phytol. 2005, 167, 645-663. [CrossRef] [PubMed]

3. Flowers, T.; Yeo, A. Breeding for salinity resistance in crop plants: Where next? Funct. Plant Biol. 1995, 22, 875-884. [CrossRef]

4. Jørgensen, F.; Scheer, W.; Thomsen, S.; Sonnenborg, T.O.; Hinsby, K.; Wiederhold, H. Transboundary geophysical mapping of geological elements and salinity distribution critical for the assessment of future sea water intrusion in response to sea level rise. Hydrol. Earth Syst. Sci. 2012, 16, 1845-1862.

5. Morrissey, E.M.; Gillespie, J.L.; Morina, J.C.; Franklin, R.B. Salinity affects microbial activity and soil organic matter content in tidal wetlands. Glob. Chang. Biol. 2014, 20, 1351-1362. [CrossRef] [PubMed]

6. Golldack, D.; Lüking, I.; Yang, O. Plant tolerance to drought and salinity: Stress regulating transcription factors and their functional significance in the cellular transcriptional network. Plant Cell Rep. 2011, 30, 1383-1391. [CrossRef] [PubMed]

7. Hasegawa, P.M. Sodium $\left(\mathrm{Na}^{+}\right)$homeostasis and salt tolerance of plants. Environ. Exp. 2013, 92, $19-31$. [CrossRef]

8. Munns, R.; Tester, M. Mechanisms of salinity tolerance. Annu. Rev. Plant Biol. 2008, 59, 651-681. [CrossRef]

9. Aslamsup, R.; Bostansup, N.; Mariasup, M.; Safdar, W. A critical review on halophytes: Salt tolerant plants. J. Med. Plant Res. 2011, 5, 7108-7118.

10. Shabala, S. Learning from halophytes: Physiological basis and strategies to improve abiotic stress tolerance in crops. Ann. Bot. 2013, 112, 1209-1221. [CrossRef]

11. Flowers, T.J.; Colmer, T.D. Salinity tolerance in halophytes. New Phytol. 2008, 179, 945-963. [CrossRef] [PubMed]

12. Reef, R.; Lovelock, C.E. Regulation of water balance in mangroves. Ann. Bot. 2014, 115, 385-395. [CrossRef] [PubMed]

13. Uzilday, B.; Ozgur, R.; Sekmen, A.H.; Yildiztugay, E.; Turkan, I. Changes in the alternative electron sinks and antioxidant defence in chloroplasts of the extreme halophyte Eutrema parvulum (Thellungiella parvula) under salinity. Ann. Bot. 2014, 115, 449-463. [CrossRef] [PubMed]

14. Jha, R.K.; Patel, J.; Mishra, A.; Jha, B. Introgression of Halophytic Salt Stress-responsive Genes for Developing Stress Tolerance in Crop Plants. In Halophytes and Climate Change: Adaptive Mechanisms and Potential Uses; CABI: Boston, MA, USA, 2019; p. 275.

15. Mangu, V.R.; Ratnasekera, D.; Yabes, J.C.; Wing, R.A.; Baisakh, N. Functional screening of genes from a halophyte wild rice relative Porteresia coarctata in Arabidopsis model identifies candidate genes involved in salt tolerance. Curr. Plant Biol. 2019, 18, 100107. [CrossRef]

16. Chang, L.; Wang, B.; Wang, D.; Li, P.; Wang, L. Comparative proteomics of Thellungiella halophila leaves from plants subjected to salinity reveals the importance of chloroplastic starch and soluble sugars in halophyte salt tolerance. Mol. Cell. Proteom. 2013, 12, 2174-2195.

17. Kosová, K.; Vítámvás, P.; Prášil, I.T.; Renaut, J. Plant proteome changes under abiotic stress—Contribution of proteomics studies to understanding plant stress response. J. Proteom. 2011, 74, 1301-1322. [CrossRef]

18. Hossain, Z.; Khatoon, A.; Komatsu, S. Soybean proteomics for unraveling abiotic stress response mechanism. J. Proteome Res. 2013, 12, 4670-4684. [CrossRef]

19. Gao, F.; Zhou, Y.; Huang, L.; He, D.; Zhang, G. Proteomic analysis of long-term salinity stress-responsive proteins in Thellungiella halophila leaves. Sci. Bull. 2008, 53, 3530-3537. [CrossRef]

20. Askari, H.; Edqvist, J.; Hajheidari, M.; Kafi, M.; Salekdeh, G.H. Effects of salinity levels on proteome of Suaeda aegyptiaca leaves. Proteomics 2006, 6, 2542-2554. [CrossRef]

21. Sugihara, K.; Hanagata, N.; Dubinsky, Z.; Baba, S.; Karube, I. Molecular characterization of cDNA encoding oxygen evolving enhancer protein 1 increased by salt treatment in the mangrove Bruguiera gymnorrhiza. Plant Cell Physiol. 2000, 41, 1279-1285. [CrossRef]

22. Yi, X.; Sun, Y.; Yang, Q.; Guo, A.; Chang, L.; Wang, D.; Yi, X.; Huang, Q.; Peng, M.; Guo, A.; et al. Quantitative proteomics of Sesuvium portulacastrum leaves revealed that ion transportation by V-ATPase and sugar accumulation in chloroplast played crucial roles in halophyte salt tolerance. J. Proteom. 2014, 99, 84-100. [CrossRef] [PubMed]

23. Moghaieb, R.E.; Saneoka, H.; Fujita, K. Effect of salinity on osmotic adjustment, glycinebetaine accumulation and the betaine aldehyde dehydrogenase gene expression in two halophytic plants, Salicornia europaea and Suaeda maritima. Plant Sci. 2004, 166, 1345-1349. [CrossRef] 
24. Joseph, D.; Chakraborty, K.; Subin, C.S.; Vijayan, K.K. Halophytes of Chenopodiaceae and Aizoaceae from south-east coast of India as potential sources of essential nutrients and antioxidants. J. Food Nut. Res. 2013, 1, 97-107.

25. Parida, A.K.; Jha, B. Antioxidative defense potential to salinity in the euhalophyte Salicornia brachiate. J. Plant Growth Regul. 2010, 29, 137-148. [CrossRef]

26. Joshi, M.; Mishra, A.; Jha, B. NaCl plays a key role for in vitro micropropagation of Salicornia brachiata, an extreme halophyte. Ind. Crops Prod. 2012, 35, 313-316. [CrossRef]

27. Krishnamurthi, S.S.; George, S.; Meenakshisundram, S.; Parida, A. Proteomic analysis of long term salt responsive proteins in the halophyte 'Suaeda maritima'. Plant Omics 2017, 10, 197. [CrossRef]

28. Benjamin, J.J.; Lucini, L.; Jothiramshekar, S.; Parida, A. Metabolomic insights into the mechanisms underlying tolerance to salinity in different halophytes. Plant Physiol. Biochem. 2019, 135, 528-545. [CrossRef]

29. Alhdad, G.M.; Seal, C.E.; Al-Azzawi, M.J.; Flowers, T.J. The effect of combined salinity and waterlogging on the halophyte Suaeda maritima: The role of antioxidants. Environ. Exp. 2013, 87, 120-125. [CrossRef]

30. Tiwari, V.; Patel, M.K.; Chaturvedi, A.K.; Mishra, A.; Jha, B. Functional characterization of the tau class glutathione-S-transferases gene (SbGSTU) promoter of Salicornia brachiata under salinity and osmotic stress. PLoS ONE 2016, 11, e0148494. [CrossRef]

31. Charon, C.; Vivancos, J.; Mazubert, C.; Paquet, N.; Pilate, G.; Dron, M. Structure and vascular tissue expression of duplicated TERMINAL EAR1-like paralogues in poplar. Planta 2010, 231, 525-535. [CrossRef]

32. Zhang, H.; Han, B.; Wang, T.; Chen, S.; Li, H.; Zhang, Y.; Dai, S. Mechanisms of plant salt response: Insights from proteomics. J. Proteome Res. 2011, 11, 49-67. [CrossRef] [PubMed]

33. Bogeat-Triboulot, M.B.; Brosché, M.; Renaut, J.; Jouve, L.; Le Thiec, D.; Fayyaz, P. Gradual soil water depletion results in reversible changes of gene expression, protein profiles, ecophysiology, and growth performance in Populus euphratica, a poplar growing in arid regions. Plant Physiol. 2007, 143, 876-892. [CrossRef] [PubMed]

34. Zhang, J.L.; Shi, H. Physiological and molecular mechanisms of plant salt tolerance. Photosynth. Res. 2013, 115, 1-22. [CrossRef] [PubMed]

35. Clipson, N. Salt tolerance in the halophyte Suaeda maritima L. Dum. growth, ion and water relations and gas exchange in response to altered salinity. J. Exp. Bot. 1987, 38, 1996-2004. [CrossRef]

36. Wang, S.M.; Zhang, J.L.; Flowers, T.J. Low-affinity $\mathrm{Na}^{+}$uptake in the halophyte Suaeda maritima. Plant Physiol. 2007, 145, 559-571. [CrossRef] [PubMed]

37. Schöttler, M.A.; Tóth, S.Z. Photosynthetic complex stoichiometry dynamics in higher plants: Environmental acclimation and photosynthetic flux control. Front. Plant Sci. 2014, 5, 188.

38. Flexas, J.; Bota, J.; Loreto, F.; Cornic, G.; Sharkey, T. Diffusive and metabolic limitations to photosynthesis under drought and salinity in C3 plants. Plant Biol. 2004, 6, 269-279. [CrossRef]

39. Lawlor, D.W.; Tezara, W. Causes of decreased photosynthetic rate and metabolic capacity in water-deficient leaf cells: A critical evaluation of mechanisms and integration of processes. Ann. Bot. 2009, 103, 561-579. [CrossRef]

40. Li, J.H.; Gale, J.; Novoplansky, A.; Barak, S.; Volokita, M. Response of tomato plants to saline water as affected by carbon dioxide supplementation. II: Physiological responses. J. Hortic. Sci. Biotechnol. 1999, 74, $238-242$. [CrossRef]

41. Tezara, W.; Mitchell, V.; Driscoll, S.; Lawlor, D. Water stress inhibits plant photosynthesis by decreasing coupling factor and ATP. Nature 1999, 401, 914. [CrossRef]

42. Kirchhoff, H.; Horstmann, S.; Weis, E. Control of the photosynthetic electron transport by PQ diffusion microdomains in thylakoids of higher plants. BBA-Bioenergetics 2000, 1459, 148-168. [CrossRef]

43. Krieger-Liszkay, A.; Kienzler, K.; Johnson, G.N. Inhibition of electron transport at the cytochrome b6f complex protects photosystem II from photoinhibition. FEBS Lett. 2000, 486, 191-194. [CrossRef]

44. Kohzuma, K.; Cruz, J.A.; Akashi, K.; Hoshiyasu, S.; Munekage, Y.N.; Yokota, A.; Kramer, D.M. The long-term responses of the photosynthetic proton circuit to drought. Plant Cell Environ. 2009, 32, 209-219. [CrossRef] [PubMed]

45. Schöttler, M.A.; Flügel, C.; Thiele, W.; Bock, R. Knock-out of the plastid-encoded PetL subunit results in reduced stability and accelerated leaf age-dependent loss of the cytochrome b6f complex. J. Biol. Chem. 2007, 282, 976-985. [CrossRef] 
46. Rott, M.; Martins, N.F.; Thiele, W.; Lein, W.; Bock, R.; Kramer, D.M.; Schöttler, M.A. ATP synthase repression in tobacco restricts photosynthetic electron transport, $\mathrm{CO} 2$ assimilation, and plant growth by overacidification of the thylakoid lumen. Plant Cell 2011, 23, 304-321. [CrossRef]

47. Pang, Q.; Chen, S.; Dai, S.; Chen, Y.; Wang, Y.; Yan, X. Comparative proteomics of salt tolerance in Arabidopsis thaliana and Thellungiella halophile. J. Proteome Res. 2010, 9, 2584-2599. [CrossRef]

48. Lucini, L.; Bernardo, L. Comparison of proteome response to saline and zinc stress in lettuce. Front. Plant Sci. 2015, 6, 240. [CrossRef]

49. Sharma, P.; Jha, A.B.; Dubey, R.S.; Pessarakli, M. Reactive oxygen species, oxidative damage, and antioxidative defense mechanism in plants under stressful conditions. J. Bot. 2012, 2012, 217037. [CrossRef]

50. Kosová, K.; Vítámvás, P.; Urban, M.O.; Klíma, M.; Roy, A.; Prášil, I.T. Biological networks underlying abiotic stress tolerance in temperate crops-A proteomic perspective International. Int. J. Mol. Sci. 2015, 16, 20913-20942. [CrossRef]

51. Hamilton, E.W.; Heckathorn, S.A. Mitochondrial adaptations to NaCl. Complex I is protected by anti-oxidants and small heat shock proteins, whereas complex II is protected by proline and betaine. Plant Physiol. 2011, 126, 1266-1274. [CrossRef]

52. De Cássia Alves, R.; de Medeiros, A.S.; Nicolau, M.C.M.; Neto, A.P.; Lima, L.W.; Tezotto, T.; Gratão, P.L. The partial root-zone saline irrigation system and antioxidant responses in tomato plants. Plant Physiol. Biochem. 2018, 127, 366-379. [CrossRef] [PubMed]

53. Kosová, K.; Prášil, I.T.; Vítámvás, P. Protein contribution to plant salinity response and tolerance acquisition. Int. J. Mol. 2013, 14, 6757-6789. [CrossRef] [PubMed]

54. Geilfus, C.M.; Zörb, C.; Mühling, K.H. Salt stress differentially affects growth-mediating $\beta$-expansins in resistant and sensitive maize (Zea mays L.). Plant Physiol. Biochem. 2010, 48, 993-998. [CrossRef] [PubMed]

55. Jones, L.; McQueen-Mason, S. A role for expansins in dehydration and rehydration of the resurrection plant Craterostigma plantagineum. FEBS lett. 2004, 559, 61-65. [CrossRef]

56. Du, C.X.; Fan, H.F.; Guo, S.R.; Tezuka, T.; Li, J. Proteomic analysis of cucumber seedling roots subjected to salt stress. Phytochemistry 2010, 71, 1450-1459. [CrossRef] [PubMed]

57. Fatehi, F.; Hosseinzadeh, A.; Alizadeh, H.; Brimavandi, T. The proteome response of Hordeum spontaneum to salinity stress. Cereal Res. Commun. 2012, 41, 78-87. [CrossRef]

58. Sobhanian, H.; Razavizadeh, R.; Nanjo, Y.; Ehsanpour, A.A.; Jazii, F.R.; Motamed, N.; Komatsu, S. Proteome analysis of soybean leaves, hypocotyls and roots under salt stress. Proteome Sci. 2010, 8, 19. [CrossRef]

59. Joshi, R.; Ramanarao, M.V.; Lee, S.; Kato, N.; Baisakh, N. Ectopic expression of ADP ribosylation factor 1 (SaARF1) from smooth cordgrass (Spartina alterniflora Loisel) confers drought and salt tolerance in transgenic rice and Arabidopsis. Plant Cell Tiss Org. 2014, 117, 17-30. [CrossRef]

60. Karan, R.; Subudhi, P.K. Overexpression of an adenosine diphosphate-ribosylation factor gene from the halophytic grass Spartina alterniflora confers salinity and drought tolerance in transgenic Arabidopsis. Plant Cell Rep. 2014, 33, 373-384. [CrossRef]

61. Kim, D.K.; Kesawat, M.S.; Hong, C.B. One gene member of the ADP-ribosylation factor family is heat-inducible and enhances seed germination in Nicotiana tabacum. Genes Genom. 2017, 39, 1353-1365. [CrossRef]

62. Berger, S.L. The complex language of chromatin regulation during transcription. Nature 2007, $447,407$. [CrossRef] [PubMed]

63. Choi, K.; Zhao, X.; Kelly, K.A.; Venn, O.; Higgins, J.D.; Yelina, N.E.; Hardcastle, T.J.; Ziolkowski, P.A.; Copenhaver, G.P.; Franklin, F.C.H.; et al. Arabidopsis meiotic crossover hot spots overlap with H2A. Z nucleosomes at gene promoters. Nat. Genet. 2013, 45, 1327. [CrossRef] [PubMed]

64. Lu, P.Y.; Levesque, N.; Kobor, M.S. NuA4 and SWR1-C: Two chromatin-modifying complexes with overlapping functions and components. Biochem. Cell Biol. 2009, 87, 799-815. [CrossRef] [PubMed]

65. Mizuguchi, G.; Shen, X.; Landry, J.; Wu, W.H.; Sen, S.; Wu, C. ATP-driven exchange of histone H2AZ variant catalyzed by SWR1 chromatin remodeling complex. Science 2004, 303, 343-348. [CrossRef] [PubMed]

66. Sokol, A.; Kwiatkowska, A.; Jerzmanowski, A.; Prymakowska-Bosak, M. Up-regulation of stress-inducible genes in tobacco and Arabidopsis cells in response to abiotic stresses and ABA treatment correlates with dynamic changes in histone H3 and H4 modifications. Planta 2007, 227, 245-254. [CrossRef] [PubMed]

67. Tuteja, N.; Banu, M.S.A.; Huda, K.M.K.; Gill, S.S.; Jain, P.; Pham, X.H.; Tuteja, R. Pea p68, a DEAD-box helicase, provides salinity stress tolerance in transgenic tobacco by reducing oxidative stress and improving photosynthesis machinery. PLoS ONE 2014, 9, e98287. [CrossRef] [PubMed] 
68. Sanan-Mishra, N.; Pham, X.H.; Sopory, S.K.; Tuteja, N. Pea DNA helicase 45 overexpression in tobacco confers high salinity tolerance without affecting yield. Proc. Natl. Acad. Sci. USA 2005, 102, 509-514. [CrossRef]

69. Gammulla, C.G.; Pascovici, D.; Atwell, B.J.; Haynes, P.A. Differential proteomic response of rice (Oryza sativa) leaves exposed to high-and low-temperature stress. Proteomics 2011, 11, 2839-2850. [CrossRef] [PubMed]

70. Pham, X.H.; Reddy, M.K.; Ehtesham, N.Z.; Matta, B.; Tuteja, N. A DNA helicase from Pisum sativum is homologous to translation initiation factor and stimulates topoisomerase I activity. Plant J. 2000, 24, $219-229$. [CrossRef]

71. Vashisht, A.A.; Pradhan, A.; Tuteja, R.; Tuteja, N. Cold-and salinity stress-induced bipolar pea DNA helicase 47 is involved in protein synthesis and stimulated by phosphorylation with protein kinase C. Plant J. 2005, 44, 76-87. [CrossRef]

72. Santosh Rama Bhadra Rao, T.; Vijaya Naresh, J.; Sudhakar Reddy, P.; Reddy, M.K.; Mallikarjuna, G. Expression of Pennisetum glaucum eukaryotic translational initiation factor 4A (PgeIF4A) confers improved drought, salinity, and oxidative stress tolerance in groundnut. Front. Plant Sci. 2017, 8, 453. [CrossRef] [PubMed]

73. Nath, M.; Garg, B.; Sahoo, R.K.; Tuteja, N. PDH45 overexpressing transgenic tobacco and rice plants provide salinity stress tolerance via less sodium accumulation. Plant Signal. Behav. 2015, 10, e992289. [CrossRef] [PubMed]

74. Wen, B.Q.; Xing, M.Q.; Zhang, H.; Dai, C.; Xue, H.W. Rice Homeobox Transcription Factor HOX1a Positively Regulates Gibberellin Responses by Directly Suppressing EL1 F. J. Integr. Plant Biol. 2011, 53, 869-878. [CrossRef] [PubMed]

75. Ma, Y.; Hendershot, L.M. ER chaperone functions during normal and stress conditions. J. Chem. Neuroanat. 2004, 28, 51-65. [CrossRef] [PubMed]

76. Malhotra, J.D.; Kaufman, R.J. The endoplasmic reticulum and the unfolded protein response. In Seminars in Cell E Developmental Biology; Elsevier: Amsterdam, The Netherlands, 2007; Volume 6, pp. 716-731.

77. Lv, S.; Jiang, P.; Chen, X.; Fan, P.; Wang, X.; Li, Y. Multiple compartmentalization of sodium conferred salt tolerance in Salicornia europaea. Plant Physiol. Biochem. 2012, 51, 47-52. [CrossRef] [PubMed]

78. UniProt. Available online: www.uniprot.org (accessed on 16 January 2020).

(C) 2020 by the authors. Licensee MDPI, Basel, Switzerland. This article is an open access article distributed under the terms and conditions of the Creative Commons Attribution (CC BY) license (http://creativecommons.org/licenses/by/4.0/). 